\title{
Evaluasi Pembelajaran Daring di Masa Pandemi Covid-19 pada Mata Kuliah Fisiologi Olahraga
}

\author{
Rika Sepriani ${ }^{1}$, Ambyar $^{2}$, Ishak Aziz ${ }^{3}$ \\ ${ }^{1,3}$ Fakultas Ilmu Keolahragaan, Universitas Negeri Padang, Indonesia \\ ${ }^{2}$ Fakultas Teknik, Universitas Negeri Padang, Indonesia. \\ E-mail:rikasepriani@fik.unp.ac.id ${ }^{1}, \underline{\text { ambyar@ft.unp.ac.id }{ }^{2}}$, ishakaziz@,fik.unp.ac.id
}

Menerima: 22 November 2020; Revisi: 03 April 2021; Diterima: 23 April 2021

https://doi.org/10.24036/MensSana.06012021.12

\begin{abstract}
The problem in this study is that there has not been an evaluation of online learning through $e$ learning during the Covid-19 pandemic in the Sports Physiology course. For this reason, this study aims to determine the achievement of online learning that has been carried out until mid-semester as a form of learning evaluation. In this study, the sample was obtained from students who took the Sports Physiology lecture who met the inclusion criteria as many as 58 people. This type of research is a quantitative descriptive study using two methods, survey methods namely in the form of a questionnaire to determine the ability of students to access e learning and an essay test to determine student learning outcomes until mid-semester, especially in the cognitive aspects. The results showed that students had been able to access e learning well and had a good average value of learning outcomes.
\end{abstract}

Keywords: evaluation, online learning, e-learning, sport physiology

Abstrak

Masalah dalam penelitian ini adalah belum dilakukannya evaluasi pembelajaran daring melalui e learning di masa pandemi Covid-19 pada mata kuliah Fisiologi Olahraga. Untuk itu penelitian ini bertujuan untuk mengetahui ketercapaian pembelajaran daring yang telah dilakukan hingga pertengahan semester sebagai bentuk evaluasi pembelajaran. Dalam penelitian ini sampel diperoleh dari mahasiswa yang mengikuti perkuliahan Fisiologi Olahraga yang memenuhi kriteria inklusi sebanyak 58 orang. Jenis penelitian ini adalah peneltian deskriptif kuantitatif dengan menggunakan dua metode yaitu metode survey berupa angket untuk mengetahui kemampuan mahasiswa mengakses e learning dan tes essay untuk mengetahui hasil belajar mahasiswa hingga pertengahan semester khususnya pada aspek kognitif. Hasil penelitian didapatkan bahwa mahasiswa telah mampu mengakses e learning dengan baik dan memiliki nilai rata-rata hasil belajar yang baik.

Kata Kunci: evaluasi, pembelajaran daring, e-learning, Fisiologi Olahraga

\section{PENDAHULUAN}

Keberhasilan suatu pendidikan dapat dilihat setelah dilakukan suatu evaluasi terhadap output atau lulusan yang dihasilkannya. Jika output lulusan hasilnya sesuai dengan tujuan pendidikan maka usaha pendidikan itu dapat dinilai berhasil. Evaluasi pembelajaran dilakukan untuk mengetahui tingkat keberhasilan peserta didik. Dalam ruang lingkup yang lebih luas, evaluasi pembelajaran dilakukan untuk mengetahui kelebihan dan kelemahan proses pembelajaran dalam mencapai tujuan pendidikan. Dalam bidang pendidikan, evaluasi pembelajaran merupakan salah satu aktivitas pendidikan. Sebagai seorang pendidik 
proses evaluasi pembelajaran berguna untuk pengambilan keputusan khususnya dan dunia pendidikan pada umumnya.

Menurut Undang-Undang Republik Indonesia Nomor 20 tahun 2003 tentang Sistem Pendidikan Nasional pasal 57 ayat 1, evaluasi dilakukan dalam rangka pengendalian mutu pendidkan secara nasional sebagai bentuk akuntabilitas penyelenggara pendidikan kepada pihak-pihak berkepentingan diantaranya terhadap peserta didik, lembaga dan program pendidikan. Evaluasi pendidikan mencakup semua komponen, proses pelaksanaan dan produk pendidikan secara total, dan di dalamnya terakomodasi tiga konsep yaitu memberikan pertimbangan (judgment), nilai (value), dan arti (worth) [1]

Evalusi pembelajaran mencakup empat bagian yaitu evaluasi input, evalusi proses, evaluasi hasil/produk dan evaluasi outcomes/dampak. Evaluasi input seperti evaluasi pada calon mahasiswa yang akan melaksankan pembelajaran nantinya. Evaluasi proses merupakan evaluasi yang dilakukan terhadap proses atau kegiatan pendidikan atau pembelajaran yang sedang berlangsung, sedangkan evaluasi hasil/produk adalah eveluasi yang dilakukan terhadap lulusan nantinya. Dan evaluasi outcomes (dampak) adalah evaluasi untuk mengukur taraf atau ketercapaian sebuah program yang menyebabkan perubahan seseorang dalam kehidupan selanjutnya[2, $\mathrm{p}$. $15]$.

Diawal tahun 2020, dunia digemparkan dengan merebaknya virus baru yaitu coronavirus jenis baru (SARS-CoV- 2) dan penyakitnya disebut Coronavirus disease 2019 (COVID-19). Diketahui, asal mula virus ini berasal dari Wuhan, Tiongkok. Ditemukan pada akhir Desember tahun 2019. Sampai saat ini sudah dipastikan terdapat 65 negara yang telah terjangkit virus satu ini [3, p. 187]. Pandemi covid-19 menjadi kendala bagi semua kalangan di dunia dan ini juga merupakan krisis kesehatan bagi manusia [4, p. 289]. Pemerintah telah melakukan berbagai macam cara untuk memutus mata rantai penyebaran COVID-19 ini mulai dari memberlakukan social distancing, physical distancing hingga memberlakukan pembatasan sosial berskala besar (PSBB).
Mudahnya virus korona menular antar manusia membuat banyak negara menutup kegiatan belajar mengajar di sekolah atau kampus [5, p. 136]. Penutupan sementara lembaga pendidikan sebagai upaya menahan penyebaran pendemi covid-19 di seluruh dunia berdampak pada jutaan pelajar, tidak terkecuali di Indonesia [6, p. 395]. Gangguan dalam pembelajaran tentu terjadi namun diharapkan setiap stakeholder yang terlibat dapat berperan dalam membangun pembelajaran yang sesuai dan tepat pada saat kondisi pandemi Covid-19.

Di Indonesia, sejak bulan Maret 2020 proses pendidikan disemua sektor baik sekolah dasar dan menengah hingga perguruan tinggi dilakukan dengan pembelajaran jarak jauh (PJJ) sebagai antisipasi penularan Covid-19 dalam masyarakat. Pembelajaran jarak jauh dapat dilakukan dengan pembelajaran dalam jaringan (daring). Menurut Darmasyah dalam Afif Riyanda, dkk [7, p. 66] sistem pembelajaran daring merupakan salah satu upaya yang bisa dilakukan untuk mengatasi permasalahan dan memudahkan mahasiswa untuk mengakases materi perkuliahan, saling berkomunikasi dan berdiskusi secara online, serta memperoleh bantuan sharing tutorial oleh dosen yang tersedia di media sistem pembelajaran daring.

Pembelajaran daring merupakan sistem pembelajaran yang dilakukan dengan tidak bertatap muka langsung, tetapi menggunakan platform yang dapat membantu proses belajar dan mengajar yang dilakukan meskipun jarak jauh[8, p. 498]. Tujuan dari adanya pembelajaran daring adalah memberikan layanan pembelajaran bermutu dalam jaringan yang bersifat masif dan terbuka untuk menjangkau peminat ruang belajar agar lebih banyak dan lebih luas [8, p. 498].

Salah satu media pembelajaran daring yang dapat digunakan dalam pembelajaran jarak jauh adalah e-learning. E-learning merupakan sistem pembelajaran elektronik yang memberikan kesempatan kepada mahasiswa untuk dapat mengeksplorasi pembelajaran secara online sekaligus sebagai jembatan pembelajaran yang fleksibel dimana saja dan kapan saja[9, p. 207].

Media e-learning mampu meningkatkan interaktivitas dan efisisensi belajar karena $e$ - 
learning melibatkan mahasiswa untuk menggali potensi dan berkomunikasi lebih banyak dengan dosen, rekan serta mengakses lebih banyak materi pembelajaran. E-learning adalah pembelajaran yang dilakukan menggunakan perangkat komputer atau perangkat elektronik untuk mendukung pembelajaran. E-learning adalah sebuah interaktivitas yang menarik minat dan perhatian peserta didik dengan melibatkan peserta didik dalam setiap pengalaman belajar pada proses pembelajaran [9, p. 207].

Universitas Negeri Padang merupakan salah satu kampus yang telah lama melakukan pembelajaran menggunakan media e-learning tersebut. E-learning mulai diperkenalkan sejak tahun 2013 dan semakin dipertegas penggunaannya pada tahun 2018 melalui peraturan Rektor No. 08 tahun 2018 [10, p. 3]. Jadi sesungguhnya, penggunaan e-learning dalam proses pembelajaran bukanlah hal yang baru bagi Universitas Negeri Padang.

Mata kuliah Fisiologi Olahraga merupakan salah satu mata kuliah wajib pada kurikulum perkuliahan di Fakultas Ilmu Keolahragaan yang diberikan sebanyak 2 sks setelah mahasiswa mengambil dan lulus mata kuliah Anatomi dan Fisiologi. Fisiologi Olahraga merupakan mata kuliah yang mempelajari tentang adaptasi-adaptasi tubuh akibat aktivitas fisik tertentu.

Selama ini proses pembelajaran pada mata kuliah fisiologi olahraga dilakukan secara tatap muka sepenuhnya dan jika melaksanakan pembelajaran secara daring maka hanya sebagai suplemen saja dalam pembelajaran. Namun, dengan adanya kondisi pandemi Covid-19 seperti sekarang ini maka pembelajaran yang semulanya dilakukan secara tatap muka harus dilakukan sepenuhnya secara daring sehingga mahasiswa tampak sedikit "syok" dengan sistem pembelajaran yang dilakukan sehingga dikhawatirkan akan menganggu proses pembelajaran nantinya dan tujuan pembelajaran yang telah ditentukan tidak tercapai.

Selain itu, proses pembelajaran daring yang telah dilakukan tersebut memerlukan evaluasi baik dari pihak perguran tinggi maupun dari dosen sendiri sebagai pelaksana dalam perkuliahan maupun dari mahasiswa sebagai penggunana. Evaluasi pembelajaran dilakukan untuk mengetahui kelebihan dan kelemahan proses pembelajaran yang dilakukan untuk mencapai tujuan pembelajaran.

Penelitian terkait dengan evaluasi pembelajaran daring telah dilakukan oleh peneliti lainnya, salah satunya yang dilakukan oleh Aan Widiyono (2020) terkait efektifitas perkuliahan daring pada mahasiswa PGSD didapatkan hasil bahwa untuk mendapatkan pembelajaran yang efektif perkuliahan dapat dilakukan dengan daring dan luring secara bergantian [11].

Sedangkan menurut Aprilia dan Dedi (2020) tentang bagaimana efektifitas penggunaan media belajar pada sistem pembelajaran daring menyatakan bahwa pelaksanaan kegiatan pembelajaran online belum maksimal dam belum efektif. Efektivitas pembelajaran daring dipengaruhi oleh kemampuan guru atau dosen [12].

Berdasarkan hal tersebut diatas maka peneliti tertarik untuk melakukan penelitian terkait dengan evaluasi pembelajaran daring di masa pandemi Covid-19 pada mata kuliah Fisiologi Olahraga. Dimana penelitian ini bertujuan untuk mengetahui ketercapaian pembelajaran daring pada mata kuliah Fisiologi Olahraga.

\section{METODE}

Penelitian ini merupakan penelitian deskriptif kuantitaif. Populasi penelitian adalah mahasiswa yang mengambil mata kuliah Fisiologi Olahraga pada semester Juli-Desember 2020. Sampel didapatkan melalui metode purposive sampling yaitu sampel yang memenuhi kriteria inklusi yang ditetapkan yaitu 1) terdaftar sebagai mahasiswa yang mengambil matakuliah Fisiologi Olahraga 2) memenuhi kriteria akademik sebagai peserta yang mengikuti perkuliahan dan 3) bersedia menjadi responden pada penelitian. Sehingga didapatkan sampel sebanyak 58 orang.

Pengumpulan data dilakukan dengan dua metode yaitu 1) menggunakan metode survey yang dilakukan dengan menyebarkan angket atau kuisioner secara online kepada mahasiswa untuk mengetahui kemampuan mahasiswa terhadap pembelajaran daring melalui media elearning dan 2) Melalui tes essay untuk 
mengetahui hasil pembelajaran siswa pada mata kuliah Fisiologi Olahraga.

Komponen-komponen yang terdapat pada angket atau kuisioner terdiri atas beberapa pertanyaan yaitu 1) Saya dapat mengoperasikan komputer/laptop 2) Saya memiliki koneksi jaringan internet untuk pembelajaran daring 3) Kemudahan jaringan dalam mengakses elearning pada saat jam pelajaran 4) Activity pada e-learning mendukung proses perkuliahan 5) Saya mengunduh materi yang diberikan dosen 6) Saya memahami materi yang diberikan dosen melalui e learning 7) Saya dapat mengumpulkan tugas melalui e learning 8) Saya mengumpulkan tugas tepat waktu 9) Saya dapat mengakses resources yang disediakan dosen dalam pembelajaran 10) E learning membentu saya dalam pembelajaran dimasa pandemi Covid-19.

Hasil belajar mahasiswa didapatkan dari Ujian Tengah Semester dengan tes essay sesuai dengan indikator-indikator yang ditetapkan oleh dosen pengampu mata kuliah. Hasil belajar yang didapatkan digunakan pengaktegorian dari peraturan akademik UNP [13, p. 44]. Data dianalisis menggunakan analisis deskriptif menggunakan persentase.

\section{HASIL DAN PEMBAHASAN}

\section{A. Hasil Penelitian}

Dari penelitian yang telah dilakukan didapatkan hasil sebagi berikut:

\section{Karakteristik Responden}

Responden pada penelitian ini adalah mahasiswa yang terdaftar pada mata kuliah Fisiologi Olahraga semester Juli-Desember 2020 Jurusan Pendidikan Olahraga Fakultas Ilmu Keolahragaan Universitas Negeri Padang. Mahasiswa kriteria akademik sebagai peserta perkuliahan dan bersedia sebagai responden pada umumnya berasal dari BP 2018 dan 2019 dan beberapa dari BP 2015-2017.

Mahasiswa tersebut masuk melalui 4 jalur yaitu melalui undangan, bidik misi, SBMPTN dan mandiri. Untuk lebih jelasnya dapat dilihat pada tabel 1 dan tabel 2 berikut:

Tabel 1. Jumlah mahasiswa berdasarkan tahun masuk (BP)

\begin{tabular}{|c|c|c|}
\hline Tahun Masuk & $\begin{array}{c}\mathrm{Fa} \\
\text { (orang) }\end{array}$ & Fr \\
\hline 2019 & 30 & $52 \%$ \\
\hline 2018 & 13 & $22 \%$ \\
\hline
\end{tabular}

\begin{tabular}{|c|c|c|}
\hline 2017 & 0 & $0 \%$ \\
\hline 2016 & 11 & $19 \%$ \\
\hline 2015 & 4 & $7 \%$ \\
\hline Jumlah & 58 & $100 \%$ \\
\hline
\end{tabular}

Tabel 2. Jumlah mahasiswa berdasarkan jalur masuk

\begin{tabular}{|c|c|c|}
\hline Jalur Masuk & $\begin{array}{c}\mathrm{Fa} \\
\text { (orang) }\end{array}$ & Fr \\
\hline Undangan & 7 & $12 \%$ \\
\hline Bidik Misi & 1 & $2 \%$ \\
\hline SBMPTN & 21 & $36 \%$ \\
\hline Mandiri & 29 & $50 \%$ \\
\hline Jumlah & 58 & $100 \%$ \\
\hline
\end{tabular}

Dari tabel dapat dilihat bahwa pada umumnya mahasiswa yang menjadi responden pada penelitian ini berasal dari jalur masuk mandiri (29 orang) dan SBMPTN (21 orang) dan beberapa dari jalur undangan (7 orang) dan bidik misi (1 orang).

2. Kemampuan mahasiswa menggunakan elearning pada mata kuliah Fisiologi Olahraga

Pelaksanaan perkuliah daring memerlukan evaluasi perguruan tinggi dan juga memerlukan evaluasi dari Dosen dan para mahasiswa [11, p. 172]. Kemampuan mahasiswa dalam menggunakan e-learning yang disediakan pada mata kuliah Fisiologi Olahraga ditinjau dari beberapa aspek seperti kemampuan mahasiswa dalam menggunakan komputer/laptop, kondisi jaringan internet di tempat masing-masing, kemudahan mengakses e-learning pada saat pembelajaran, penggunaan activity yang ada pada e-learning dan penggunaan e learning dalam pembelajaran di masa pandemi Covid19 pada mata kuliah Fisiologi Olahraga. Untuk lebih jelasnya dapat dilihat pada gambar dibawah ini.

a. Mengoperasikan komputer/laptop

Dari 58 responden yang mengisi kuisioner penelitian yang diberikan pada umumnya dapat menguasai dan menggunakan laptop atau komputer dengan baik. Hal ini dapat dilihat pada jawaban yang diberikan responden melalui angket yang diberikan sepert dibawah ini. 
Tabel 3. Kemampuan mengoperasikan komputer/laptop

\begin{tabular}{|c|c|c|}
\hline Jawaban & $\mathrm{Fa}$ & $\mathrm{Fr}$ \\
\hline Sangat menguasai & 1 & $2 \%$ \\
\hline Menguasai & 42 & $72 \%$ \\
\hline Tidak menguasai & 10 & $17 \%$ \\
\hline Sangat tidak menguasai & 5 & $9 \%$ \\
\hline Jumlah & 58 & $100 \%$ \\
\hline
\end{tabular}

b. Koneksi jaringan internet untuk pembelajaran daring

Dari 58 responden yang mengisi angket/kuisioner penelitian yang diberikan pada umumnya memiliki koneksi internet yang baik di tempatnya masing-masing hanya beberapa saja yang memiliki koneksi internet yang buruk. Untuk lebih jelasnya dapat dilihat pada tabel dibawah ini.

Tabel 4. Koneksi jaringan internet

\begin{tabular}{|c|c|c|}
\hline Jawaban & $\mathrm{Fa}$ & $\mathrm{Fr}$ \\
\hline Sangat Baik & 1 & $2 \%$ \\
\hline Baik & 35 & $60 \%$ \\
\hline Buruk & 19 & $33 \%$ \\
\hline Sangat Buruk & 3 & $5 \%$ \\
\hline Jumlah & 58 & $100 \%$ \\
\hline
\end{tabular}

c. Kemudahan jaringan dalam mengakses $e$ learning pada saat perkuliahan

Dari 58 orang responden yang mengisi angket yang diberikan sebagian besar responden menjawab bahwasanya koneksi jaringan $e$ learning pada saat pembelajaran memiliki koneksi jaringan yang buruk. Hanya beberapa saja yang dapat mengakses e-learning dengan baik pada saat pembelajaran. Untuk lebih jelasnya dapat dilihat pada tabel dibawah ini.

Tabel 5. Akses e-learning pada saat pembelajaran

\begin{tabular}{|c|c|c|}
\hline Jawaban & $\mathrm{Fa}$ & $\mathrm{Fr}$ \\
\hline Sangat baik & 4 & $7 \%$ \\
\hline Baik & 16 & $28 \%$ \\
\hline Buruk & 38 & $66 \%$ \\
\hline Sangat buruk & 0 & $0 \%$ \\
\hline Jumlah & 58 & $100 \%$ \\
\hline
\end{tabular}

d. Activity pada e-learning mendukung proses perkuliahan

Dari 58 orang responden yang mengisi angket yang diberikan lebih dari setengahnya $(60 \%)$ menjawab setuju bahwa activity yang disediakan pada e-learning dapat mendukung proses perkuliahan hanya beberapa saja yang tidak setuju (16\%). Untuk lebih jelasnya dapat dilihat pada tabel dibawah ini.

Tabel 6. Activity e-learning mendukung perkuliahan

\begin{tabular}{|c|c|c|}
\hline Jawaban & $\mathrm{Fa}$ & $\mathrm{Fr}$ \\
\hline Sangat setuju & 11 & $19 \%$ \\
\hline Setuju & 38 & $66 \%$ \\
\hline Tidak Setuju & 8 & $14 \%$ \\
\hline Sangat tidak setuju & 1 & $2 \%$ \\
\hline Jumlah & 58 & $100 \%$ \\
\hline
\end{tabular}

e. Mengunduh materi yang diberikan dosen

Dari 58 orang responden yang menjawab angket yang diberikan, sebanyak 37 orang mahasiswa sering mengunduh materi yang diberikan oleh dosen pada e-learning (64\%), hanya $7 \%$ saja yang jarang mengunduh materi yang diberikan dosen pada e learning. Untuk lebih jelasnya dapat dilihat pada tabel dibawah ini.

Tabel 7. Mengunduh materi yang diberikan dosen

\begin{tabular}{|c|c|c|}
\hline Jawaban & $\mathrm{Fa}$ & $\mathrm{Fr}$ \\
\hline Sangat setuju & 11 & $19 \%$ \\
\hline Setuju & 38 & $66 \%$ \\
\hline Tidak Setuju & 8 & $14 \%$ \\
\hline Sangat tidak setuju & 1 & $2 \%$ \\
\hline Jumlah & 58 & $100 \%$ \\
\hline
\end{tabular}

f. Memahami materi yang diberikan dosen melalui e-learning

Dari 58 orang responden yang menjawab angket yang diberikan, sebagian dapat memahami materi yang diberikan $(60 \%)$ dan sebagian lagi kurang dapat memahami materi yang diberikan (40\%). Untuk lebih jelasnya dapat dilihat pada tabel dibawah ini.

Tabel 8. Memahami materi dosen 


\begin{tabular}{|c|c|c|} 
Sangat Baik & 12 & $20 \%$ \\
\hline Baik & 23 & $40 \%$ \\
\hline Kurang & 23 & $40 \%$ \\
\hline Sangat Kurang & 0 & $0 \%$ \\
\hline Jumlah & 58 & $100 \%$ \\
\hline
\end{tabular}

g. Mengumpulkan tugas melalui e learning

Dari 58 orang responden yang mengisi angket yang diberikan hampir semuanya dapat dapat mengumpulkan tugas melalui e-learning $(90 \%)$ hanya beberapa saja yang tidak mengumpulkan tugas melalui e-learning. Untuk lebih jelasnya dapat dilihat pada tabel dibawah ini.

Tabel 9. Mengumpulkan tugas melalui $e$ learning

\begin{tabular}{|l|r|r|}
\hline Jawaban & Fa & Fr \\
\hline Selalu & 24 & $41 \%$ \\
\hline Sering & 28 & $48 \%$ \\
\hline Kadang-kadang & 6 & $10 \%$ \\
\hline Tidak pernah & 0 & $0 \%$ \\
\hline Jumlah & 58 & $100 \%$ \\
\hline
\end{tabular}

h. Mengumpulkan tugas tepat waktu

Dari 58 orang responden yang mengisi angket yang diberikan, sebagian dapat mengumpulkan tugas tepat waktu melalui $e$ learning $(65 \%)$ dan sebagian lagi tidak dapat mengumpulkan tugas tepat waktu melalui $e$ learning. Untuk lebih jelasnya dapat dilihat pada tabel dibawah ini.

Tabel 10. Mengumpulkan tugas tepat waktu

\begin{tabular}{|c|c|c|}
\hline Jawaban & Fa & Fr \\
\hline Selalu & 10 & $17 \%$ \\
\hline Sering & 28 & $48 \%$ \\
\hline Kadang-kadang & 20 & $34 \%$ \\
\hline Tidak pernah & 0 & $0 \%$ \\
\hline Jumlah & 58 & $100 \%$ \\
\hline
\end{tabular}

i. Mengakses resources yang disediakan dosen pada e-learning

Dari 58 orang responden yang mengisi angket yang diberikan, hampir semuanya dapat mengakses resources yang disediakan dosen $(81 \%)$, hanya beberapa saja yang tidak dapt mengakses resources yang disediakan dosen (9\%). Untuk lebih jelasnya dapat dilihat pada tabel dibawah ini.

Tabel 11. Mengakses resources yang disediakan dosen pada e-learning

\begin{tabular}{|c|c|c|}
\hline Jawaban & $\mathrm{Fa}$ & $\mathrm{Fr}$ \\
\hline Sangat baik & 6 & $10 \%$ \\
\hline Baik & 47 & $81 \%$ \\
\hline Buruk & 5 & $9 \%$ \\
\hline Sangat Buruk & 0 & $0 \%$ \\
\hline Jumlah & 58 & $100 \%$ \\
\hline
\end{tabular}

j. E-learning membantu pembelajaran dimasa pandemi Covid-19

Dari 58 orang responden yang mengisi angket yang diberikan, hampir semuanya setuju bahwa e-learning dapat membantu pembelajaran di masa pandemi covid-19 ini (91\%) hanya beberapa saja yang tidak setuju $(9 \%)$. Untuk lebih jelasnya dapat dilihat pada tabel dibawah ini

Tabel 12. E-learning membantu pembelajaran dimasa pandemi Covid-19

\begin{tabular}{|c|c|c|}
\hline Jawaban & $\mathrm{Fa}$ & $\mathrm{Fr}$ \\
\hline Sangat setuju & 18 & $31 \%$ \\
\hline Setuju & 28 & $48 \%$ \\
\hline Tidak setuju & 8 & $14 \%$ \\
\hline Sangat tidak setuju & 4 & $7 \%$ \\
\hline Jumlah & 58 & $100 \%$ \\
\hline
\end{tabular}

\section{Hasil Belajar Mahasiswa pada Mata Kuliah Fisiologi Olahraga}

Hasil belajar mahasiwa pada matakuliah fisiologi olahraga didapatkan dengan menggunakan tes essay berdsarkan indikatorindikator yang ditetapkan oleh dosen pengampu mata kuliah. Dari tes yang telah dilaksanakan maka didaptkan hasil belajar mahasiswa pada mata kuliah fisiologi olahraga dengan nilai tertinggi 100 dan nilai terendah 50 dengan nilai rata-rata 73,6 .

Jika mengacu pada standar penialian yang ditetapkan oleh UNP maka semua mahasiswa dapat dikatakan lulus pada mata kuliah Fisiologi Olahraga yang ditandai dengan tidak adanya mahasiswa yang mendapatkan nilai gagal. Untuk lebih jelasnya dapat dilihat pada gambar dibawah ini 


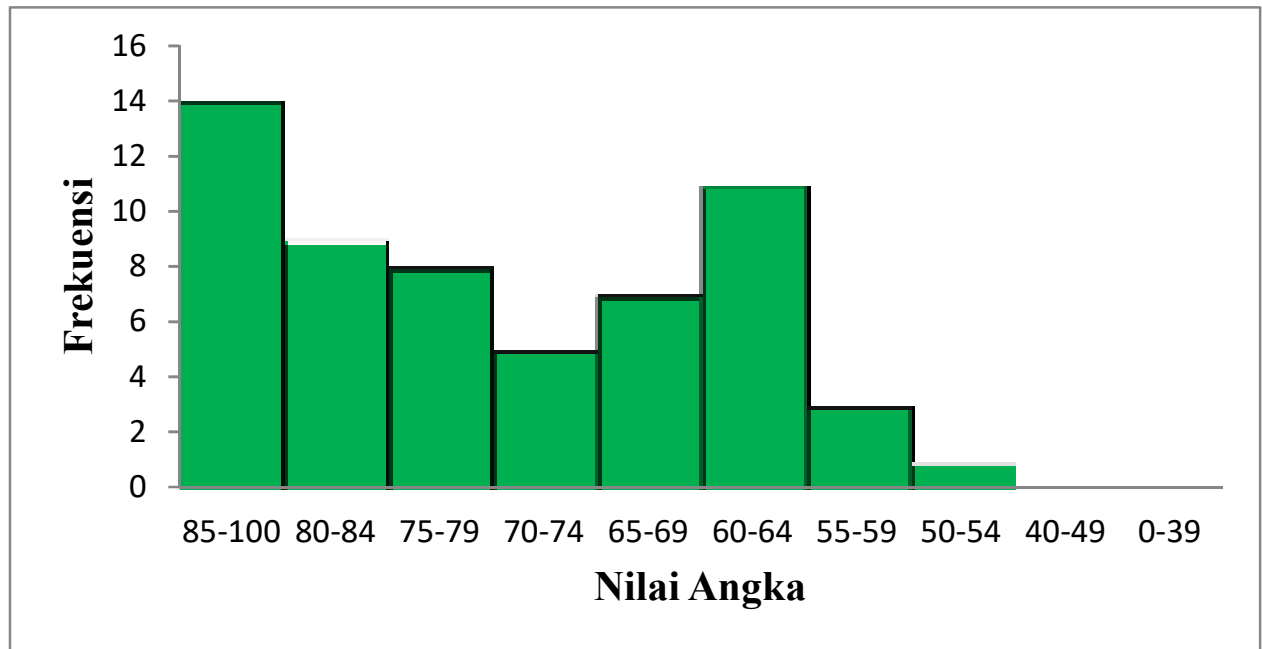

Gambar 1. Hasil Belajar Mata Kuliah Fisiologi Olahraga

\section{B. Pembahasan}

\section{Karakteristik Responden}

Berdasarkan hasil penelitian yang telah dilakukan terhadap 58 orang mahaiswa yang memenuhi kriteria inklusi yang berasal dari berbagai jalur masuk yaitu Undangan, Bidik Misi, SBMPTN dan Mandiri dengan tahun masuk 2015 sampai 2019 yang mengikuti mata kuliah Fisiologi Olahraga didapatkan hasil bahwasanya responden pada penelitian ini berasal dari jalur masuk mandiri (29 orang) dan SBMPTN (21 orang) dan beberapa dari jalur undangan (7 orang) dan bidik misi (1 orang).

Kriteria ini telah sesuai dengan peraturan akdemik Universitas Negeri Padang pasal 10 tentang jalur masuk penerimaan mahasiswa yaitu penerimaan mahasiswa dapat dilakukan melalui seleksi nasional (tes maupun non tes), seleksi mandiri dan seleksi bidang olahraga dan seni $[13$, p. 17]

\section{Kemampuan mahasiswa dalam menggunakan e-learning}

Kemampuan mahasiswa dalam menggunakan e-learning didapatkan dengan menggunakan instrumen angket. Angket diberikan kepada mahasiswa secara online karena memang tidak dimungkinkannya pengambilan data secara langsung karena situasi pandemi Covid-19. Angket yang diberikan terdapat 11 pernyataan terkait dengan kemampuan mahasiswa dalam menggunakan e learning yang disediakan oleh Universitas Negeri Padang. Pada angket yang diberikan terdapat 10 pernyataan terkait dengan kemampuan mahasiswa dalam menggunakan e learning dalam proses pembelajaran pada mata kuliah fisiologi olahraga.

a. Mengoperasikan komputer/laptop

Dari 58 responden yang mengisi kuisioner penelitian yang diberikan pada umumnya dapat menguasai dan menggunakan laptop atau komputer dengan baik yaitu sebanyak $72 \%$ dan yang tidak menguasai/tidak mampu menggunakan laptop sebanyak $10 \%$.

Dari hasil tersebut dapat dilihat bahwasanya mahasiswa yang mengikuti mata kuliah Fisiologi Olahraga secara daring menggunakan e-learning sebagian besar telah memenuhi persyaratan dalam mengikuti perkuliahan daring. Laptop atau komputer merupakan sarana yang dibutuhkan dalam pembelajaran daring.

Hal ini sesuai dengan oktavia [8, p. 497] bahwa fasilitas penunjang yang dibutuhkan dalam pembelajaran daring adalah smartphone, laptop, komputer ataupun tablet yang digunakan untuk mengakses informasi diamnapun dan kapanpun. 
b. Koneksi jaringan internet untuk pembelajaran daring.

Selain laptop atau komputer, sarana lainnya yang dibutuhkan dalam melakukan pembelajaran daring adalah jaringan internet itu sendiri. Berdasarkan angket yang disebabarkan kepada mahasiwa, tampak bahwa mahasiswa yang mengikuti pembelajaran daring tersebar dari berbagai propinsi baik berdomisili di kota ataupun kabupaten sehingga memiliki koneksi internet yang tidak sama.

Koneksi internet merupakan hal vital yang dibutuhkan dalam pembelajaran daring. Berdasarkan angket yang diberikan, mahasiwa yang mengikuti pembelajaran fisiologi olahraga memiliki koneksi internet yang baik sebanyak $62 \%$ dan sisanya memilki koneksi internet yang buruk.

Tanpa memiliki koneksi jaringan internet yang baik, mustahil dapat melakukan pembelajaran daring secara maksimal sehingga tujuan pembelajaran yang telah direncanakan dapat tercapai. Untuk itu dibutuhkan koneksi internet yang baik bagi setiap orang yang melakukan pembelajaran daring, tidak hanya mahasiswa tetapi juga dosen sebagai pelaksana pembelajaran.

Seperti yang dikutip dari Isman dalam Dewi $[14$, p. 56] bahwa pembelajaran daring merupakan pembelajaran yang dilakukan dengan memanfaatkan jaringan internet dalam pembelajaran. Untuk mengatasi hal tersebut, dosen yang mengampu mata kuliah Fisiologi Olahraga untuk dapat memperhatikan hal terkait dengan ketersedian jaringan pada mahasiswa dalam mengikuti perkuliahan.

Tugas yang diberikan sebaiknya diberikan rentang waktu tertentu yang memungkinkan mahasiswa untuk dapat menyelesaikannya dengan baik sehingga tujuan pembelajaran yang diinginkan dapat tercapai.

c. Kemudahan jaringan dalam mengakses $e$ learning pada saat perkuliahan

Dari penelitian yang dilakukan didapatkan hasil bahwasanya koneksi jaringan e-learning pada saat pembelajaran memiliki koneksi jaringan yang buruk (66\%). Hanya beberapa saja yang dapat mengakses $e$ -
Hal ini disebabkan karena trafic akses $e$ learning yang tinggi pada saat jam pembelajaran berlangsung sehingga hal ini secara langsung akan menganggu jalannya proses pembelajaran.

Dosen dapat megatasi hal tersebut dengan menggunakan platform pembelajaran daring yang lain sebagai komplemen dalam pembelajaran yang dilakukan sehingga tujuan pembelajaran yang diharapkan dapat tercapai. Selain itu, pihak universitas diharapkan dapat menambah daya server yang dimilikinya sehingga dapat mengatasi permasalahan terkait trafic akses e-learning pada jam pelajaran.

d. Activity pada e-learning mendukung proses perkuliahan

Dari penelitian yang dilakukan didapatkan data bahwa mahasiswa setuju tentang activity yang tersedia di dalam $e$ learning mampu menunjang proses pembelajaran fisiologi olahraga $(66 \%)$. Activity yang disediakan di dalam e-learning pada hakikatnya sama dengan semua kegiatan yang dilakukan pada perkuliahan tatap muka.

Universitas Negeri Padang telah melengakapi e-learning dengan berbagai activity sperti adanya attendance untuk merekap kehadiran mahasiswa, assignment sebagai media penugasan oleh dosen kepada mahasiswa, discuss sebagai tempat diskusi yang dibutuhkan selama pembelajaran, serta dilengakapi juga dengan berbagai macam fitur lain untuk menjadikan pembelajaran daring memiliki esensi yang sama dengan pembelajaran konvensional.

Hal ini sesuai dengan peraturan Rektor $[10$, p. 3] tentang bentuk dan standar pelaksanaan e learning bahwa e-learning mencakup aktivitas seperti kehadiran, tugas, diskusi dan evaluasi seperti yang biasa dilakukan pada pembelajaran konvensional sehingga tidak ada perbedaan dalam pelaksanaan pembelajaran.

e. Mengunduh materi yang diberikan dosen

Dari data hasil penelitian didapatkan bahwasanya sebanyak 37 orang mahasiswa sering mengunduh materi yang diberikan oleh dosen pada e-learning (64\%), hanya $7 \%$ saja yang jarang mengunduh materi yang diberikan dosen pada e-learning. Mahasiswa dapat mengunduh materi yang di upload dosen 
melalui e-learning untuk dipelajari oleh mahasiswa secara mandiri. Pembelajaran daring merupakan pembelajaran yang menuntut kemandirian mahasiswa dalam belajar dimana mahasiswa menjadi pusat dalam pembelajaran (student center) dan dosen hanya sebagai fasilitator.

f. Memahami materi yang diberikan dosen melalui e-learning

Setiap pembelajaran yang dilakukan tentu memilki tujuan yang harus dicapai. Agar tujuan pembelajaran tercapai tentu membutuhkan pemahaman mahasiswa terkait dengan materi yang diberikan. Berdasarkan data hasil penelitian yang telah didapatkan tampak bahwa sebagian besar $(60 \%)$ mahasiswa bisa memahami materi yang diberikan dosen melalui e-learning dan sebagian lagi $(40 \%)$ kurang bisa memahami materi yang diberikan.

Untuk mahasiswa yang kurang memahami materi yang diberikan dosen diharapkan keaktifan mahasiswa tersebut untuk mencari referensi lain terkait dengan materi yang diberikan. Apalagi dengan keterbukaan informasi seperti sekarang sangat mendukung kegiatan belajar mandiri mahasiswa.

$$
\text { g. Mengumpulkan tugas melalui e }
$$

Sebagai bentuk penguatan dalam proses pembelajaran dosen dapat melakukannya dalam bentuk pemberian tugas kepada mahasiswa. Penguatan dalam pembelajaran bertujuan untuk mendapapatkan respon yang diinginkan sesuai dengan tujuan pembelajaran [15, p. 27]. Pada beberapa pertemuan dalam pembelajaran fisiologi olahraga dosen memberikan tugas terkait materi yang diberikan.

Mahasiswa diminta untuk mengerjakan tugas yang diberikan sesuai dengan waktu yang telah ditetapkan. Dari penelitian yang telah dilakukan didapatkan hasil bahwa hampir semua mahasiswa (89\%) dapat mengirimkan tugas melaui e-learning.

Dari hal tersebut dapat dilihat bahwa mahasiswa sudah mampu dalam mengumpulkan tugas melalui e-learning karena penggunaan e-learning bukanlah hal yang baru dalam proses pembelajaran di Universitas Negeri Padang.

Apalagi karakteristik mahasiwa sebagai generasi milenial yang memilki kemampuan yang baik terkait pemanfaatan teknologi informasi sehingga tidak memilki kendala yang bearti tentang pengiriman tugas melalui e-learning [16, p. 131].

h. Mengumpulkan tugas tepat waktu

Dari penelitian yang dilakukan didapatkan hasil bahwasanyan sebagian besar mahasiswa dapat mengumpulkan tugas tepat waktu (65\%) sesuai dengan waktu yang telah ditetapkan.

Dari hal tersebut dapat dilihat bahwasanya waktu yang dberikan oleh dosen pengampu mata kuliah kepada mahasisiwa untuk mengerjakan tugas yang diberikan telah sesuai dengan yang seharusnya. Waktu yang diberikan dirasa cukup bagi mahsiswa untuk memahamai materi yang diberikan serta dapat mengatasi segala hambatan dalam perkuliahan seperti ketersedian jaringan dan koneksi internet

i. Mengakses resources yang disediakan dosen pada e-learning

Dari penelitian yang telah dilakukan didapatkan hasil bahwa hampir semuanya dapat mengakses resources yang disediakan dosen $(81 \%)$, hanya beberapa saja yang tidak dapt mengakses resources yang disediakan dosen (9\%). Hal ini menunjukkan bahwa mahasiswa telah mampu dalam menggunakan $e$-learning dengan baik karena penggunaan $e$ learning yang bukanlah hal baru bagi mahasiswa di Universitas Negeri Padang.

E-learning di Universitas Negeri Padang telah mulai diperkenalkan semenjak tahun 2013. Dengan mengakses resources yang disediakan dosen dalam perkuliahan menunjukkan bahwasanya mahasiswa telah dapat mengikuti perkuliahan daring dengan menggunakan e-learning dengan baik. Ini merupakan salah satu faktor penting dalam proses pembelajaran. 
j. E-learning membantu pembelajaran dimasa pandemi Covid-19

Secara keseluruhan mahasiwa menganggap bahwa pembelajaran secara daring melalui e-learning sangat membantu mereka dalam pembelajaran dimasa pandemi covid-19 dimana sebanyak $79 \%$ mahasiswa setuju terhadap pembelajaran daring dimasa pandemi covid-19. E-learning sebagai hasil langsung dari teknologi dan pendidikan telah muncul sebagai media pembelajaran yang ampuh terutama yang menggunakan internet. Signifikansi dari e-learning dalam pendidikan telah menyebabkan pertumbuhan besarbesaran dalam jumlah pembelajaran dan jenis layanan yang ditawarkan oleh e-learning [17, p. 67].

Pembelajaran secara daring merupakan satu-satunya solusi untuk menekan penyebaran covid-19. Dalam pembelajaran daring mahasiswa merasa lebih nyaman untuk bertanya dan mengemukakan pendapat dalam forum yang dilaksanakan secara online. Pembelajaran secara online yang mengarah pada student centered mampu memunculkan tanggung jawab dan otonomi mahasiswa dalam belajar [8, p. 501].

Selain itu, pembelajaran secara daring lebih praktis dan tidak memerlukan biaya yang banyak dan tidak mengahbiskan banyak "kuota" mahasiswa dalam pembelajaran. Dolan et al. (2015) juga menyatakan bahwasanya pembelajaran daring adalah cara belajar yang efektif baik dalam aplikasi teoritis maupun praktis [18, p. 21].

\section{Hasil Belajar Mata Kuliah Fisiologi Olahraga}

Hasil belajar adalah pengetahuan dan kemampuan yang dimiliki mahasiswa setelah menjalani pengalaman belajarnya. Hasil belajar dapat dilihat melalui evalusi pembelajaran yang dapat diukur kesesuainnya dengan tujuan pembelajaran [9, p. 208]. Menurut Bloom dalam Ratnawulan dan Rusdiana hasil belajar dapat dikelompokkan dalam tiga domain yaitu kognitif, afektif dan psikomotor. Pada penelitian ini hasil belajar yang diukur berupa domain kognitif saja [2, p. 63].

Berdasarkan penelitian yang telah dilakukan didapatkan bahwa hasil belajar mahasiswa yang mengikuti mata kuliah fisiologi olahraga melalui Ujian Tengah Semester (UTS) memiliki nilai maksimum 100 dan nilai minimum 50 dengan nilai rata-rata 73,6 .

Ujian Tengah Semester (UTS) merupakan penialian yang dilakukan untuk mengetahui kemampuan mahasiswa selama setengah semester $[19$, p. 206]. Jika kita mengacu pada nilai mutu yang ditetapkna oleh Universitas Negeri Padang melalui peraturan akademiknya [13, p. 44] dapat dilihat bahwa semua mahasiswa lulus pada mata kuliah ini yang ditandai tidak adanya mahasiswa yang mendapatkan nilai gagal.

Secara keseluruhan nilai rata-rata yang didapatkan mahasiswa melalui tes essay pada Ujian Tengah semester (UTS) yaitu 73,6 yang menurut aturan akademik Universitas Negeri Padang berada pada nilai mutu B dengan sebutan mutu Baik.

Hal ini sejalan dengan angket yang diisi oleh mahasiswa bahwa sebagian besar $(60 \%)$ mahasiswa dapat memahami materi yang diberikan dosen dan mampu mengerjakan tugas serta mengirimkan tugas secara tepat waktu. Dalam sebuah pembelajaran setiap stimulus yang diberikan jika diberikan perlakuan yang tepat maka akan dapat memberikan respon yang sesuai dengan yang diharapakan.

Dalam pembelajaran fisiologi olahraga, dosen pengampu mata kuliah tidak hanya memberikan materi saja tetapi juga memberikan beberapa tugas yang dapat dimanfaatkan mahasiswa sebagai pembelajaran mandiri dengan mencari referensi lain sehingga materi yang didapatkan tidak hanya dari apa yang diberikan dosen tetapi juga dari referensi lain sehingga mahasiswa memiliki keluasan materi sekaligus peningkatan pemahamannya terhadap materi yang diberikan.

Pelaksanaan pembelajaran daring di masa pandemi dapat berdampak positif terhadap pembelajaran Fisiologi Olahraga yang dilakukan. Hal ini sejalan dengan penelitian yang dilakukan oleh Kinanti (2020) yang menyatakan bahwa terjadi peningkatan IPK mahasiswa Pendidikan Ekonomi dengan pembelajaran daring [20]. 
Senada dengan hal tersebut Anggrawan (2019) dan Henillawati (2020) menyatakan bahwa pembelajaran daring memiliki implikasi yang baik terhadap hasil belajar mahasisiwa [21], [22].

\section{KESIMPULAN}

Dari hasil penelitianyang diperoleh maka dapat disimpulkan bahwasanya kemampuan mahasiswa mengakses e-leraning sangat dibutuhkan dalam proses pembelajaran daring baik dari ketersedian fasilitas penunjang seperti akses intrenet dan laptop maupun dari kemampuannya mengakses activity yang disediakan.

Pada saat jam pembelajran mahasiswa sering mengalami beberapa gangguan dalam mengakses e learning seperti sering error karena padatnya "pengunjung" maka untuk itu kepada lembaga yang berwenang diharapkan untuk dapat meningkatkan kapasitas servernya sehingga mampu menampung semua pengunjung yang mengakses e learning dan proses pembelajaran dapat dilakukan sebagaimana mestinya.

\section{DAFTAR PUSTAKA}

[1] UU RI, NO.20, "Undang-Undang Republik Indonesia Nomor 23 Tentang Sistem Pendidikan Nasional,” 2003.

[2] E. Ratnawulan and Rusdiana, Evaluasi Pembelajaran. Bandung: Pustaka Setia, 2017.

[3] Y. Yuliana, "Yuliana," Wellness Heal. Mag., vol. 2, no. February, pp. 187192, 2020.

[4] Mastura and R. Santaria, "Dampak Pandemi Covid-19 terhadap Proses Pengajaran bagi Guru dan Siswa Pendahuluan," J. Stud. Guru dan Pembelajaran, vol. 3, no. 2, pp. 289 295, 2020.

[5] D. Y. Irawati and J. Jonatan, "Evaluasi Kualitas Pembelajaran Online Selama Pandemi Covid-19: Studi Kasus di Fakultas Teknik, Universitas Katolik Darma Cendika," J. Rekayasa Sist. Ind., vol. 9, no. 2, pp. 135-144, 2020.
Pendidikan di Indonesia: Sekolah, Keterampilan, dan Proses Pembelajaran," SALAM J. Sos. dan Budaya Syar-i, vol. 7, no. 5, 2020.

A. R. Riyanda, K. Herlina, and B. A. Wicaksono, "Evaluasi Implementasi Sistem Pembelajaran Daring Fakultas Keguruan dan Ilmu Pendidikan Universitas Lampung," J. IKRA-ITH Hum., vol. 4, no. 1, pp. 66-71, 2020.

[8] oktavia ika Handarini and S. S. Wulandari, "Daring to draw causal claims from non-randomized studies of primary care interventions," $J$.

Pendidik. Adm. Perkantoran, vol. 8, no. 53, pp. 496-503, 2020.

[9] T. W. Khusniyah, "Efektivitas ELearning Terhadap Hasil Belajar," vol. 4, no. 3, pp. 208-214, 2020.

[10] 2018 Universitas Negeri Padang, PerRek 2018-08 e-learning.pdf. 2018.

[11] A. Widiyono, "Efektifitas Perkuliahan Daring (Online) pada Mahasiswa PGSD di Saat Pandemi Covid 19," J. Pendidik., vol. 8, no. 2, pp. 169-177, 2020.

[12] D. Prestiadi, "Efektivitas Penggunaan Media Belajar Dengan Sistem Daring Ditengah Pandemi Covid-19," AdMathEdu J. Ilm. Pendidik. Mat. Ilmu Mat. dan Mat. Terap., vol. 4, no. January, p. 25, 2020.

[13] A. Irianto, "Peraturan Akademik Universitas Negeri Padang," p. 44, 2015.

[14] W. A. F. Dewi, "Dampak COVID-19 terhadap Implementasi Pembelajaran Daring di Sekolah Dasar," Edukatif J. Ilmu Pendidik., vol. 2, no. 1, pp. 55-61, 2020.

[15] H. B. Uno, Orientasi Baru dalam Psikologi Pembelajaran, Ke-Enam. Jakarta: Bumi Aksara, 2016.

[16] H. Muhammad et al., "Pemanfaatan Ict Sebagai Media Pembelajaran Dan Informasi Pada Uin Alauddin Makassar," vol. 6, no. 3, pp. 127-135, 2011. 
[17] D. Al-Fraihat, M. Joy, R. Masa'deh, and J. Sinclair, "Evaluating E-learning systems success: An empirical study," Comput. Human Behav., vol. 102, no. June 2019, pp. 67-86, 2020.

[18] E. Dolan, E. Hancock, and A. Wareing, "An evaluation of online learning to teach practical competencies in undergraduate health science students," Internet High. Educ., vol. 24, pp. 2125, 2015.

[19] A. Jamaludin, "Perbandingan Hasil Belajar Antara Mahasiswa Yang Bekerja Dengan Yang Tidak Bekerja Pada Matakuliah Ekonomi Mikro di STIE YPBI Jakarta," vol. 4, no. 1, pp. 198-210, 2016.

[20] K. G. Hilmiatussadiah, "Hasil belajar mahasiswa pendidikan ekonomi dengan pembelajaran daring pada masa pandemi Covid-19," J. Pendidik. Ekon. Indones., vol. 1, no. 2, pp. 66-69, 2020.

[21] Anthony Anggrawan, "Analisis Deskriptif Hasil Belajar Pembelajaran Tatap Muka dan Pembelajaran Daring Menurut Gaya Belajar Mahasiswa," $J$. Matrik, vol. 18, no. 2, pp. 339-346, 2019.

[22] S. H. Hennilawati, "Dampak Pembelajaran Daring Terhadap Hasil Belajar Mahasiswa Intitut Pendidikan Tapanuli Selatan Masa Pandemi Covid19," J. Educ. Dev., vol. 8, no. 4, pp. 413-414, 2020. 